\title{
THE INFLUENCE OF VEGETATION ON REFLECTED SOLAR RADIATION IN ARID AND EXTRA-ARID ZONE OF MONGOLIAN GOBI
}

\author{
Viktor P. Dedkov', Elena V. Danzhalova ${ }^{2}$, Sergey N .Tkachenko', Khadbaatar S. ${ }^{3}$, Ariunbold E. ${ }^{4}$ \\ Peter D. Gunin², Sergey N. Bazha* \\ 'Immanuel Kant Baltic Federal University, 14, A. Nevskogo ul., Kaliningrad, 236036, Russia \\ ${ }^{2}$ A.N. Severtsov Institute of Ecology and Evolution, Russian Academy of Sciences, 33, Leninsky Prospekt, Moscow, \\ 119071, Russia \\ ${ }^{3}$ Mongolian National University of Education, 14, Baga toiruu, Ulaanbaatar-48, 210648, Mongolia \\ 4Botanical Garden - Institute, Mongolian Academy of Sciences, 77 - Jukov avenue-77, Ulaanbaatar - 51, 13330, \\ Mongolia
}

*Corresponding author: sbazha@inbox.ru

Received: May 12 1 th 2020 / Accepted: November 20 th, 2020 / Published: December 31 12020

https://DOI-10.24057/2071-9388-2020-91

\begin{abstract}
Vegetation cover has a noticeable effect on surface reflectivity and local microclimate in arid areas of Mongolian Gobi. Over the past decades, various shrub species (Haloxylon ammodendron and Calligonum mongolicum) have appeared on the previously unvegetated hamada. The climatic consequences of bush encroachment are still poorly understood. Using the experimental data, this article estimates the reflectance of plants dominating in Mongolia's dry steppe, desert-steppe, and desert ecosystems. The average values of the total reflection coefficient at visible and infrared wavelengths range from $19.7 \% \pm 1.4 \%$ to $20.1 \% \pm 1.7 \%$ in plants growing in desert-steppe ecosystems, and from $25.0 \% \pm 0.9 \%$ to $24.8 \% \pm 1.5 \%$ on the bare surface. The difference between the reflectance of vegetated and unvegetated surfaces reaches $5 \%$. Therefore, in daylight hours, the vegetated day surface loses less solar energy than the non-vegetated surface does. This phenomenon may be defined as a quasi- or secondary greenhouse effect - in daylight hours, solar energy is retained on the surface by vegetation and this contributes to the temperature increase. Such an impulse, which seems to be insignificantly small at first glance, triggers a series of climatic variations leading to a change in the structure of the radiation and heat balance as well as the climate not only in the desert-steppe and desert ecosystems but also in Central Asia as a whole. All this may explain the $1.2-2.3^{\circ} \mathrm{C}$ increase in air temperatures in the Gobi observed over the last 25 years.
\end{abstract}

KEY WORDS: Mongolia, Gobi desert, desert-steppe, plant cover, solar radiation, reflectance, surface temperature

CITATION: Viktor P. Dedkov, Elena V. Danzhalova, Sergey N .Tkachenko, Khadbaatar S., Ariunbold E., Peter D. Gunin, Sergey N. Bazha (2020). The Influence Of Vegetation On Reflected Solar Radiation In Arid And Extra-Arid Zone Of Mongolian Gobi. Geography, Environment, Sustainability, Vol.13, No 4, p. 72-80

https://DOI-10.24057/2071-9388-2020-91

Conflict of interests: The authors reported no potential conflict of interest.

\section{INTRODUCTION}

The surface of the Earth is not uniform and climatic zones have different functions in the biosphere. Eurasia's desert-steppe zone, which occupies approximately 4 b ha (Zalibekov and Novikova 2016), is a special type of landscape that is characterised by accelerated development. In deserts, successive evolutionary changes occur much more rapidly than they do in other landscapes. Many millions of years ago, the early evolution of deserts was affected primarily by the physiographical factors - high solar radiation intensity, winds, dryness of air and soils, scarcity of precipitation, and others. The later stages of evolution were shaped by not only the physiographical but also the biotic factor - namely, the emergence of the vegetation cover and fauna. The latter had a corrective effect on ecological regimes and the trajectory of climate change (Gunin et a1. 1980; Dedkov et al. 2017).
This phenomenon has been observed in some deserts of Central Asia including the Gobi desert (Karthe et al., 2019; Gradel et al., 2019). Our data suggets that the unvegetated areas of the Gobi desert have reduced over the last 35-40 years. The desert land cover on the intergully areas (hamada) in Trans-Altai Gobi, which had a dark shade in the 1970s, looks pale-yellowish today, which is explained by the accumulation of sandy material. Large amounts of sandy material are found in the wind shadow of Haloxylon ammodendron', Calligonum mongolicum, Nitraria sphaerocarpa, and Reaumuria soongarica. The formation of sand ridges and a porous crust horizon under plants results in the emergence of biotopes that differ from gullies and inter-gully areas in terms of environmental conditions.

Over the past decades, various shrub species (Haloxylon ammodendron and Calligonum mongolicum)

'Latin names of plants are given by The Plant List (http://www.theplantlist.org/) 
have appeared on the previously unvegetated hamada (Slemnev et al. 1994; Gunin et al. 1999). The depth of gullies below the surface of inter-gully areas has decreased as a result of the accumulation of sand and gravel material. Unlike previous decades, the process taking place in gullies is accompanied by an increase in the number of shrubs and semi-shrubs characterised by a large phytomass and significant projective cover (Haloxylon ammodendron, Ajania fruticulosa, and Salsola arbuscula), as well as in the number of perennial grasses (Arnebia fimbriata, Zygophyllum potaninii, etc.).

In 1952-2013, plant communities developed and expanded in inter-gully areas, in gullies, on dunes and mountain slopes. The number of rodent colonies rose and the volume of, and area occupied by shed vegetative parts increased. A progressive expansion of Ephedra sinica and Allium polyrhizum was observed (Gunin et al. 2012; Bazha et al. 2015). Areas of low temperatures emerged and expanded above the surface of plants as well as regions of very high temperatures above the surfaces of shed vegetative parts in the mountains, on hamadas, in gullies, and on dunes. The ensuing fragmentation of biotopes increased the extremeness, dispersion, and diurnal amplitude of temperatures (Dedkov 2016). Over 60 years (1952-2013), the proportion of such degradation indicator species as Artemisia adamsii, A. frigida, Leymus chinensis, Carex duriuscula, Sibbaldianthe bifurca, Polygonum angustifolium, and others rose in the communities of Gobi's dry and desert steppes. (Bazha et al. 2012). At the same time, a good condition of typical desert steppe dominants - Allium polyrhizum, Cleistogenes songorica, Stipa tianschanica, and S. caucasica was observed alongside an increase in the number of plant species (in some places by 100\%), the projective cover, and especially the total aboveground phytomass (Kazantseva 2009; Kazantseva et al. 2015).

Animal husbandry has been Mongolia's economic specialisation since ancient period. Natural pastures account for about $70 \%$ of the country's territory or approximately $112.4 \mathrm{~m}$ ha, according to FAOSTAT, 2014. In 2016, the National Statistical Agency of Mongolia estimated the national livestock at 62 million animals (http://www.en.nso.mn/). This cannot but affect the structure of vegetation cover, surface reflectance, microclimate, and the radiation balance. A major area of vegetation cover studies is the application of remote methods based on satellite and aerial imagery of vast areas. Such studies include an assessment of plant biomass (Zhao et al. 2014, Sibanda et al. 2017); leaf area index monitoring (Rusli and Majid 2014, Kappas and Propastin 2012); analysing temporal dynamics of vegetation given phenological phases (Marstona et al. 2016); classifying plant communities (Chopping et al. 2008); assessing the quality of fodder and pasture productivity (Ali et al. 2016), and other research. The analysed parameters include various vegetative indices (Karnieli et al. 2013).

It was found that vegetation cover can have a noticeable effect on surface reflectivity and local temperatures (Bonan 2008; Brovkin et al. 2013; Collatz et al. 2000; Heck et al. 2001). At the same time, there is an opinion that in arid landscapes, the influence of vegetation on the reflectivity is insignificant due to its scarcity and strong sparseness (Curadeau et al., 2016). However, due to the active process of shrubbery in ecosystems of arid and semi-arid landscapes, which occurs in different regions of the planet (North and South America, Africa, Australia), researchers start to notice various consequences of this process, mainly concerning the changes in the soil and vegetation cover (Van Auken 2000; Knapp et al. 2008; Buffington and Herbel 1965; Cyrus et al. 2017., Archer et al. 2017). In particular, it was found that overgrowth in the Chihuahua Desert in North America leads to a change in the microclimate, namely, an increase in soil temperature and night air temperature is noted (D'Odorico et al. 2010). It should be noted that the climatic consequences of bush encroachment are still poorly understood.

It is well known, that certain applied research issues cannot be solved solely using remote methods. The value of NDVI obtained remotely depends on the species composition, vegetation density and condition, exposure and angle of inclination of the surface, the colour of the soil under sparse vegetation. Besides, the NDVI is sensitive to changes in the soil background when the projective vegetation cover is below 30\% (Cherepanov, Druzhinina 2009), which is typical for most of the studied areas.

Alongside general information on the condition of the vegetation cover, it is important to have an idea about the effect of certain plants on the transformation of surface reflectance. Studying the spectral properties of plants and plant communities is important for analysing the surface radiation balance, identifying the current causes of climate change, modelling the energy-mass exchange processes, and solving other research problems. Another urgent objective is estimating the contribution of invasive plant species to the changes in the radiation balance and microclimate structure. This data is necessary for monitoring the state of ecosystems affected by both anthropogenic factors and natural processes.

This work aims to examine the reflectance of plants in Mongolia's arid and extra-arid zone in order to study their properties and characteristics and to analyse the influence of their reflectance on climate processes and the component structure of the radiation balance. The authors analysed the reflectance of solar radiation not only for the plants under natural conditions but also for those affected by grazing. The analysis took into account weather and climate characteristics, phenological states, biotope ecology, etc. Another objective was to measure the integrated spectra of steppe and desert communities (averaged a certain area) for its later use in classifying Landsat ETM and MODIS data.

\section{METHODOLOGY AND MATERIALS PROCESSING}

The fieldwork was carried out in August - September 2013, as part of a Joint Russian-Mongolian Complex Biological Expedition (JRMCBE) - a collaboration between the Russian Academy of Sciences and the Mongolian Academy of Sciences. We worked during the maximum vegetation period, therefore, we can assume that the influence of vegetation on the surface reflectance during this period will also the highest. The sampling sites (key plots) included dry steppe communities in the Dundgovi aimag (the Delgertsogt sum), mountain steppe, desert steppe and middle desert in the Ömnögovi aimag (the Bulgan and Gurvantes sums), middle desert, true desert and extra-arid desert in the Bayankhongor aimag (the Shinejinst sum) of Mongolian Gobi (Table 1, Fig. 1).

The research team used ASD FieldSpec II UVNNIR handheld field spectroradiometer (Malvern Instruments, UK) to measure the intensity of solar radiation reflected from the surface of plants in the range of 325-1075 nm (at ultraviolet, visible, and near-infrared wavelengths). The measurement accuracy reached $+/-1.0 \mathrm{~nm}$, the resolution $-3 \mathrm{~nm}$. Measurements were possible at a viewing angle of 1-25 degrees. Due to the complex geometry of plants, the 


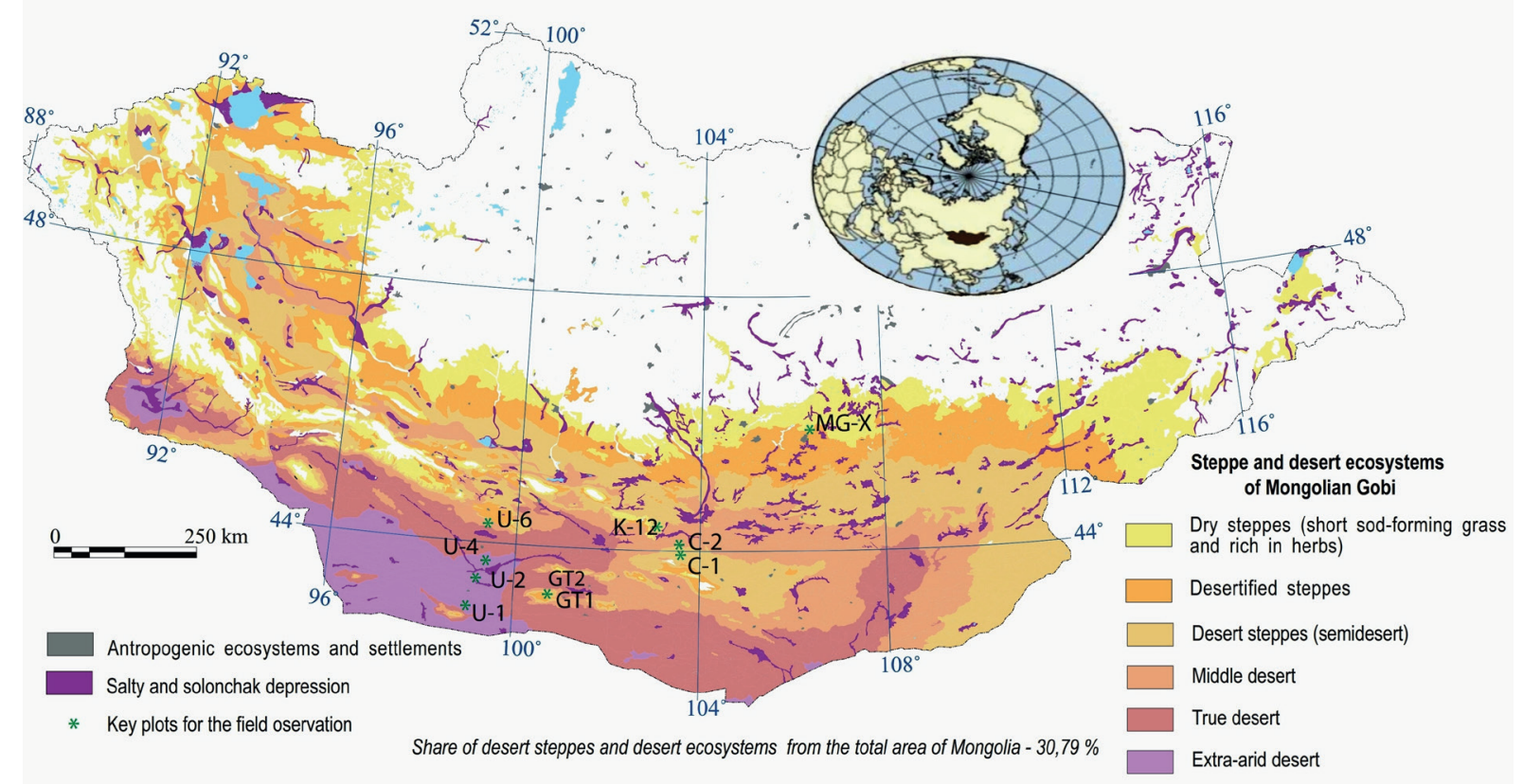

Fig. 1. Location of key plots on the Distribution Map of Subzonal Vegetation of the Mongolian Gobi (Gunin and Saandar 2019)

solar radiation reflected by plants consists of the radiation reflected by green and non-green fractions and the radiation transformed by plants. Thus, the level of the reflected signal depends on the solar elevation angle, weather conditions, phenology, the composition of plants and plant communities, and the optical properties of plants, shoots, and other vegetative and non-vegetative plant components.

Most measurements were performed at noon at a solar elevation angle of 45-55 degrees, and a viewing angle of 1 degree, the solar disc was open. White calibration was performed before each measurement. At the first stage, the spectra of the radiation reflected both by individual species and the unvegetated surface were measured. The integral spectra of the steppe and desert plant communities were measured within 30 by $30 \mathrm{~m}$ squares. In the first case, the instrument was placed in a vertical position to prevent soil reflectance at a viewing angle of 1 degree.

In the second case, the instrument was placed at an angle of 45 degrees to the surface to measure the radiation reflected by vegetation communities. Areal measurements using the 'envelope method' were performed alongside point ones. Within 30 by $30 \mathrm{~m}$ areas, measurements were performed from one corner to the opposite and then from the next corner to the opposite.

During the fieldwork, 142 spectra of reflected radiation were obtained, including 20 of steppe plant species, 65 of desert plants species, 35 of non-vegetated open areas, and 22 of plant communities.

The reflected radiation spectra were processed as follows: the 325-1075 $\mathrm{nm}$ range was divided into three parts (Shulgin 1973) - from 325 to 380 nm (UV wavelengths), 380780 nm (visible wavelengths), and 780-1075 (near-infrared wavelengths). The total reflection coefficient was calculated for each of the three ranges. The coefficient corresponds to the total quantity of solar energy reflected by the object within each range, expressed as a percentage of the initial incident solar energy or of the energy reflected from an ideal dispersion surface of radiation within the same wavelength range.

Thus, three total coefficients characterising the reflectance of a certain plant or a $30 * 30 \mathrm{~m}$ area within a relevant wavelength range were obtained for each spectrum.

\section{RESULTS AND DISCUSSION}

The analysis of the data on the reflected short-wave solar radiation spectra in the plant communities of Gobi shows that the amount of radiation does not only depend
community dominants in the arid and extra-arid zone of Table 1. Spectra of solar radiation reflection (SRR) by vegetation community dominants
Gobi, acquired on August 21 - September 03, 2013

\begin{tabular}{|c|c|c|c|c|c|c|c|c|c|}
\hline \multirow{2}{*}{$\begin{array}{l}\text { Date/ } \\
\text { Index }\end{array}$} & \multirow{2}{*}{$\begin{array}{l}\text { Subzone / plant } \\
\text { community }\end{array}$} & \multirow{2}{*}{$\begin{array}{l}\text { Coordinates, } \\
\text { Elevation, m }\end{array}$} & \multirow{2}{*}{$\begin{array}{l}\text { Time /Solar } \\
\text { elevation }\end{array}$} & \multirow{2}{*}{ Plant species } & \multirow{2}{*}{ Plant life-form } & \multicolumn{4}{|c|}{ Reflected solar radiation spectra (\%) } \\
\hline & & & & & & Total & UV & V & $\mathbb{R}$ \\
\hline \multirow{6}{*}{$\begin{array}{c}\text { 21.08.13/ } \\
\text { MG-X }\end{array}$} & \multirow{6}{*}{$\begin{array}{c}\text { Dry steppe / } \\
\text { [Caragana } \\
\text { leucophloea]-Allium } \\
\text { polyrhizum }\end{array}$} & \multirow{6}{*}{$\begin{array}{c}46^{\circ} 08^{\prime} 32^{\prime \prime} \mathrm{N} \\
106^{\circ} 30^{\prime} 46,9^{\prime \prime} \mathrm{E} \\
\mathrm{H} 1363\end{array}$} & \multirow{6}{*}{$\begin{array}{c}12.05-12.40 / \\
55.1^{\circ}\end{array}$} & A. polyrhizum & $\begin{array}{l}\text { Herbaceous } \\
\text { perennial } \\
\text { succulent }\end{array}$ & 25 & 4 & 23 & 30 \\
\hline & & & & Control & - & 29 & 4 & 26 & 36 \\
\hline & & & & $\begin{array}{c}\text { Scorzonera } \\
\text { divaricata }\end{array}$ & $\begin{array}{c}\text { Herbaceous } \\
\text { perennial }\end{array}$ & 25 & 4 & 24 & 29 \\
\hline & & & & Control & - & 28 & 4 & 27 & 32 \\
\hline & & & & $\begin{array}{l}\text { Artemisia } \\
\text { scoparia }\end{array}$ & $\begin{array}{c}\text { Herbaceous } \\
\text { biennial }\end{array}$ & 16 & 3 & 16 & 18 \\
\hline & & & & Control & - & 25 & 5 & 26 & 28 \\
\hline
\end{tabular}




\begin{tabular}{|c|c|c|c|c|c|c|c|c|c|}
\hline \multirow{2}{*}{$\begin{array}{c}24.08 .13 / \\
C-2\end{array}$} & \multirow{2}{*}{$\begin{array}{c}\text { Desert } \\
\text { steppe / Stipa } \\
\text { tianschanica+Allium } \\
\text { polyrhizum }\end{array}$} & \multirow{2}{*}{$\begin{array}{c}44^{\circ} 00^{\prime} 43.1^{\prime \prime} \mathrm{N} \\
103^{\circ} 33^{\prime} 34.8^{\prime \prime} \mathrm{E} \\
\mathrm{H} 1434\end{array}$} & \multirow{2}{*}{$\begin{array}{c}11.42-12.04 / \\
53.9^{\circ}\end{array}$} & $\begin{array}{c}\text { Krascheninnikovia } \\
\text { ceratoides }\end{array}$ & $\begin{array}{l}\text { True dwarf } \\
\text { shrub }\end{array}$ & 15 & 4 & 17 & 14 \\
\hline & & & & Control & - & 19 & 6 & 21 & 20 \\
\hline \multirow{3}{*}{$\begin{array}{l}25.08 .13 / \\
\mathrm{K}-12\end{array}$} & \multirow{3}{*}{$\begin{array}{l}\text { Middle desert / Salsola } \\
\text { passerina+Bracha } \\
\text { nthemum gobicum }\end{array}$} & \multirow{3}{*}{$\begin{array}{l}44^{\circ} 14^{\prime} 21.2^{\prime \prime} \\
N_{1} 103^{\circ} 31 \\
\text { '05.3"E } \\
\text { H } 1081\end{array}$} & \multirow{3}{*}{$\begin{array}{l}12.15-12.29 / \\
54.8^{\circ}\end{array}$} & Salsola passerina & $\begin{array}{c}\text { Succulent } \\
\text { dwarf shrub }\end{array}$ & 15 & 7 & 17 & 15 \\
\hline & & & & $\begin{array}{l}\text { Reaumuria } \\
\text { soongarica }\end{array}$ & $\begin{array}{c}\text { True dwarf } \\
\text { shrub }\end{array}$ & 26 & 11 & 30 & 26 \\
\hline & & & & Control & - & 31 & 12 & 35 & 30 \\
\hline \multirow{2}{*}{$\begin{array}{c}28.08 .13 / \\
\text { GT-1 }\end{array}$} & \multirow{2}{*}{$\begin{array}{l}\text { Mountain steppe / } \\
\text { Ephedra sinica } \\
\text { +Ajania fruticulosa } \\
\text { +Allium polyrhizum }\end{array}$} & \multirow{2}{*}{$\begin{array}{c}43^{\circ} 11^{\prime} 54,4^{\prime \prime} \mathrm{N} \\
100^{\circ} 42^{\prime} 26,4^{\prime \prime} \mathrm{E} \\
\mathrm{H} 2093\end{array}$} & \multirow{2}{*}{$\begin{array}{l}09.55-10.23 / \\
37.2^{\circ}\end{array}$} & E. sinica & Dwarf shrub & 14 & 5 & 16 & 14 \\
\hline & & & & Control & - & 20 & 5 & 19 & 25 \\
\hline \multirow{3}{*}{$\begin{array}{c}\text { 28.08.13/ } \\
\text { GT-2 }\end{array}$} & \multirow{3}{*}{$\begin{array}{c}\text { Mountain steppe } \\
\text { / Ephedra sinica (in } \\
\text { the gorge close to } \\
\text { GT-1) }\end{array}$} & \multirow{3}{*}{ - } & \multirow{3}{*}{$\begin{array}{c}10.56-11.12 / \\
45.7^{\circ}\end{array}$} & $\begin{array}{l}\text { E. sinica (parent } \\
\text { individual) }\end{array}$ & - & 13 & 2 & 11 & 17 \\
\hline & & & & $\begin{array}{c}\text { Krascheninnikovia } \\
\text { ceratoides }\end{array}$ & $\begin{array}{l}\text { True dwarf } \\
\text { shrub }\end{array}$ & 9 & 3 & 11 & 7 \\
\hline & & & & Control & - & 18 & 6 & 23 & 15 \\
\hline \multirow{3}{*}{$\begin{array}{c}29.08 .13 / \\
\text { U-1 }\end{array}$} & \multirow{3}{*}{$\begin{array}{l}\text { Extra-arid desert } \\
\text { / Haloxylon } \\
\text { ammodendron+ } \\
\text { Ephedra przewalskii }\end{array}$} & \multirow{3}{*}{$\begin{array}{c}43^{\circ} 11^{\prime} 08.1^{\prime \prime} \mathrm{N} \\
98^{\circ} 55^{\prime} 56.0^{\prime \prime} \mathrm{E} \\
\mathrm{H} 1108\end{array}$} & \multirow{3}{*}{$\begin{array}{c}11.32-11.45 / \\
49.1^{\circ}\end{array}$} & E. przewalskii & Shrub & 19 & 3 & 21 & 20 \\
\hline & & & & H. ammodendron & Shrub & 26 & 6 & 30 & 25 \\
\hline & & & & Control & - & 16 & 6 & 20 & 12 \\
\hline \multirow{5}{*}{$\begin{array}{c}30.08 .13 / \\
U-2\end{array}$} & \multirow{5}{*}{$\begin{array}{l}\text { Extra-arid desert / } \\
\text { Iljinia regelii }\end{array}$} & \multirow{5}{*}{$\begin{array}{c}43^{\circ} 22^{\prime} 29.5^{\prime \prime} \mathrm{N} \\
99^{\circ} 07^{\prime} 00.4^{\prime \prime} \mathrm{E} \\
\mathrm{H} 763\end{array}$} & \multirow{5}{*}{$\begin{array}{c}10.49-11.15 / \\
48.8^{\circ}\end{array}$} & $\begin{array}{l}\text { I. regelii (on } \\
\text { hamada) }\end{array}$ & Dwarf shrub & 12 & 6 & 15 & 9 \\
\hline & & & & $\begin{array}{l}\text { H. ammodendron } \\
\text { (on hamada) }\end{array}$ & Shrub & 15 & 7 & 19 & 11 \\
\hline & & & & Control & - & 14 & 7 & 18 & 10 \\
\hline & & & & I. regelii (on gully) & - & 7 & 2 & 6 & 8 \\
\hline & & & & Control & - & 19 & 8 & 24 & 14 \\
\hline \multirow{3}{*}{$\begin{array}{l}02.09 .13 / \\
U-4\end{array}$} & \multirow{3}{*}{$\begin{array}{l}\text { True desert / } \\
\text { Haloxylon } \\
\text { ammodendron }\end{array}$} & \multirow{3}{*}{$\begin{array}{c}43^{\circ} 57^{\prime} 23.0^{\prime \prime} \mathrm{N} \\
99^{\circ} 13^{\prime} 41.8^{\prime \prime} \mathrm{E} \\
\mathrm{H} 1264\end{array}$} & \multirow{3}{*}{$\begin{array}{l}13.54-14.28 / \\
52.5^{\circ}\end{array}$} & $\begin{array}{l}\text { H. ammodendron } \\
\text { (vegetative plant) }\end{array}$ & - & 12 & 4 & 14 & 11 \\
\hline & & & & $\begin{array}{l}\text { H. ammodendron } \\
\text { (drying plant) }\end{array}$ & - & 20 & 6 & 24 & 18 \\
\hline & & & & Control & - & 28 & 7 & 34 & 25 \\
\hline \multirow{3}{*}{$\begin{array}{l}\text { 03.09.13/ } \\
\text { U-6 }\end{array}$} & \multirow{3}{*}{$\begin{array}{l}\text { Middle desert / } \\
\text { Anabasis brevifolia }\end{array}$} & \multirow{3}{*}{$\begin{array}{c}44^{\circ} 15^{\prime} 29.8^{\prime \prime} \mathrm{N} \\
99^{\circ} 21^{\prime} 34.6^{\prime \prime} \mathrm{E}_{\prime} \\
\mathrm{H} 1253\end{array}$} & \multirow{3}{*}{$\begin{array}{l}10.43-10.58 / \\
40.8^{\circ}\end{array}$} & $\begin{array}{l}\text { Zygophyllum } \\
\text { xanthoxylon }\end{array}$ & Shrub & 5 & 2 & 5 & 5 \\
\hline & & & & $\begin{array}{l}\text { Control (on } \\
\text { hamada) }\end{array}$ & - & 19 & 7 & 21 & 18 \\
\hline & & & & Control (on gully) & - & 10 & 3 & 10 & 11 \\
\hline
\end{tabular}

on the geographical coordinates of the biotope, the absolute elevation, the phenological and physiological characteristics of plants, the structure of the crown, the feature of the surface, and the weather conditions but is also species-specific. The analysis of the data presented in table 1 (Index MG-X) suggests that, at noon, at a 4-6 tenths cloud cover (cumulus humilis), Artemisia scoparia reflects less shortwave solar radiation in the visible and infrared ranges than the other species dominating the [Caragana leucophloea]-Allium polyrhizum community in a dry steppe do.

The maximum reflected solar radiation was observed in the visible range of 525-625 $\mathrm{nm}$. The quantity of reflected solar radiation at visible wavelengths was decreasing in the $625-725 \mathrm{~nm}$ range and increasing in the near-infrared range. In the nature of changes, the signal reflected from the surface of Allium polyrhizum is similar to that observed in
Artemisia scoparia. However, the magnitude of reflectance at visible and infrared wavelengths was much higher. The reflection of solar radiation from the soil surface, which was used as a control, changes similarly to the reflection from the surfaces of plants. The only difference is that, at infrared wavelengths, the magnitude of reflection from the soil surface is higher than that from plant surfaces.

The species of the Salsola passerina+Brachanthemum gobicum community reflected more solar radiation at visible wavelengths than dry steppe plants did (Tab.1, Index K-12).

The maximum reflected radiation (up to 60\%) at visible wavelengths (525-625 nm) was observed in Zygophyllum xanthoxylon and the minimum (below 30\%) in Salsola passerina. A significant difference between these species was detected at infrared wavelengths. Reaumuria soongarica and Anabasis brevifolia were characterised by average reflected radiation values. 
In an extremely arid desert (Table 1, Index U-1; U-2), the reflected solar radiation spectrum data is mainly similar to that of plants growing in dry steppes and desert steppes. The maximum solar radiation reflected from plant surfaces at visible wavelengths was detected in the aphyllous shrub Haloxylon ammodendron, and the minimum in Ephedra przewalskii. At near-infrared wavelengths, the situation did not differ from that described above. The maximum infrared solar radiation was observed in Haloxylon ammodendron and the minimum in the shrub Calligonum mongolicum.

As it was shown above, the Gobi desert is undergoing a rapid change in the species composition accompanied by the expansion of the vegetation cover - both human-induced and natural. Earlier publications have emphasised that the expansion of vegetation communities leads to changes in the surface temperature and increasing biotope fragmentation (Dedkov et al. 2017). It is reasonable to assume that the emergence of plants and the expansion of vegetated areas will affect the reflectance, the structure of the radiation and heat balance as well as climate processes. For this purpose, quasi-synchronic observations were performed. They included measuring the radiation reflected from the surfaces of plants and the unvegetated surface (Table 1).

The data presented in table 1 suggests that the dominant plants in different vegetation communities of Gobi reflect much less shortwave solar radiation - both visible and infrared - than the unvegetated surface. At visible wavelengths, in approximately $73 \%$ of all cases, plants reflected less shortwave solar radiation than the unvegetated surface. This difference varied from biotope to biotope, ranging from -1 to -20\% (Fig. 2).

Clustering made it possible to identify the centroids as points and calculate the distances to all centroids. Each object is assigned to the nearest cluster by distance. Straight lines were used as central axes of a cluster. Objects were assigned to a cluster based on the distance to these lines. The boundary conditions were as follows - the root-mean-square error (RMSE) $\rightarrow$ min within each cluster, the R-squared value $\left(R^{2}\right)>0.6$, the total squared error $\rightarrow$ min, and the number of clusters $\rightarrow$ min.
As fig. 2 shows, based on the visible wavelengths, plants can be divided into five groups depending on the correlation between the total reflection coefficients of the unvegetated surface and the plant. Groups 1, 2, and 3 comprise species characterised by an intensity of SRR that is lower than that of the unvegetated surface. Most of the studied plants belong to one of these three groups. In group 1, which brings together Haloxylon ammodendron, Salsola passerina, and Iljinia regelii, the difference between the total coefficient of plants and the surface is very significant at visible wavelengths. In group 3, which comprises Zygophyllum rosowii and Ephedra przewalskii, this difference is rather negligible. Group 2 is characterised by a moderate difference. There is a distinct boundary between groups 1 and 2 - the distance between the nearest points assigned to groups 1 and 2 is very significant and comparable to the size of the clusters. An indirect indication of correct clustering is the approximate equality of the linear trend slopes for each cluster.

Group 4 (Haloxylon ammodendron and Stipa caucasica) and group 5 (Haloxylon ammodendron and Zygophyllum xanthoxylon) bring together plants that demonstrate a higher total reflection coefficient at visible wavelengths than the unvegetated surface. These groups are rather small in comparison to groups 1-3.

Similar results were obtained for SRR at infrared wavelengths. Over $72 \%$ of plants reflected infrared radiation less intensively that the unvegetated surface did. However, the difference between the plant surfaces and control was more significant than in the case of visible radiation, reaching 33\% (Fig. 3).

According to fig. 3, the plants can be divided into three groups based on the correlation between the unvegetated surface/plant total reflection coefficients. These groups can be described as follows. Group 1 (Allium polyrhizum, Haloxylon ammodendron, and Salsola passerina) comprises plants, whose reflection intensity is much lower than that of the adjacent unvegetated area. This is the largest group. Group 2 (Haloxylon ammodendron, Iljinia regelii, and Krascheninnikovia ceratoides)

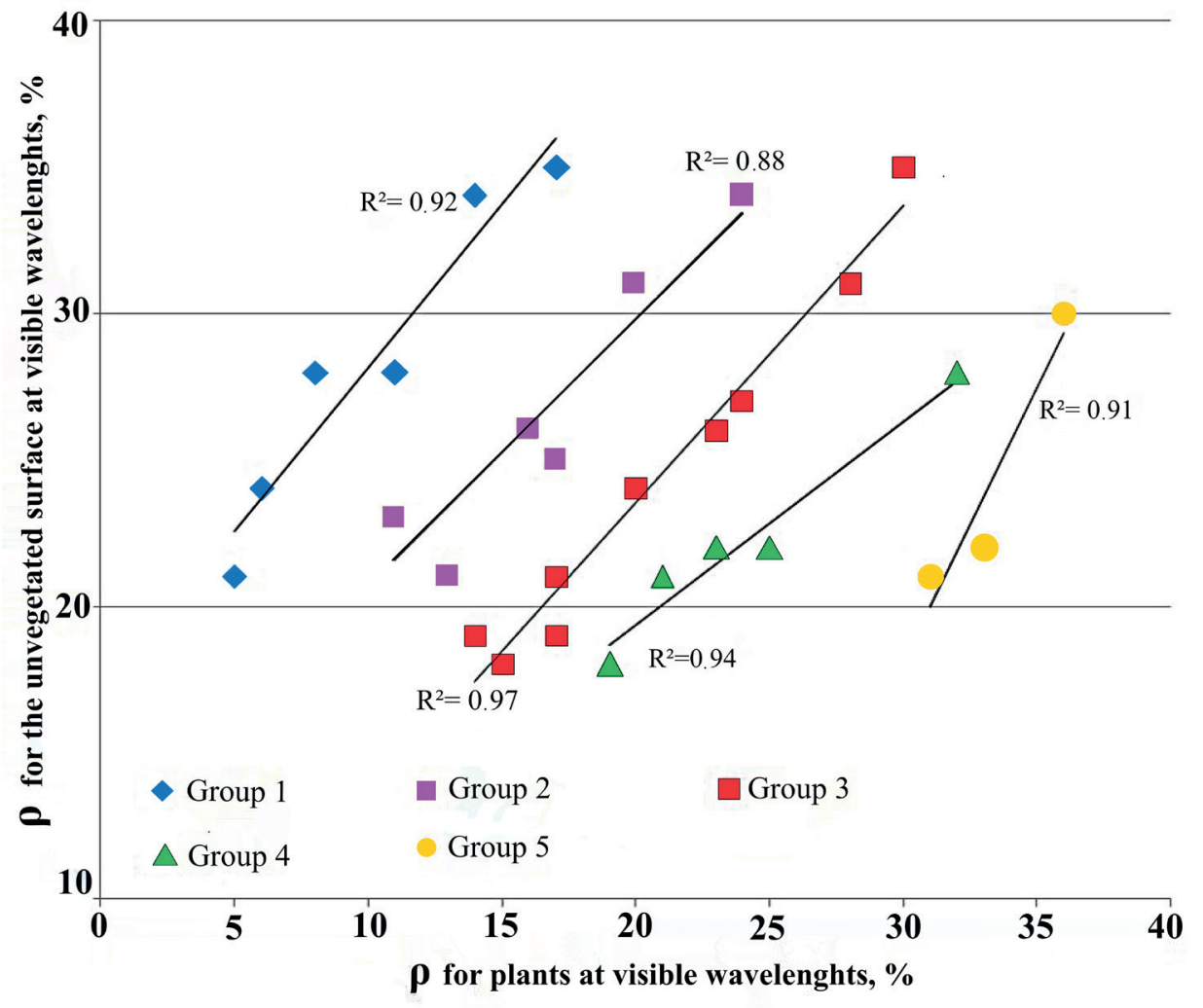

Fig. 2. The correlation between the total reflection coefficient of plants and adjacent unvegetated areas at visible wavelengths for 32 dominant species in different communities of Gobi. k-means clustering was performed using the obtained data (MacQueen 1967) 


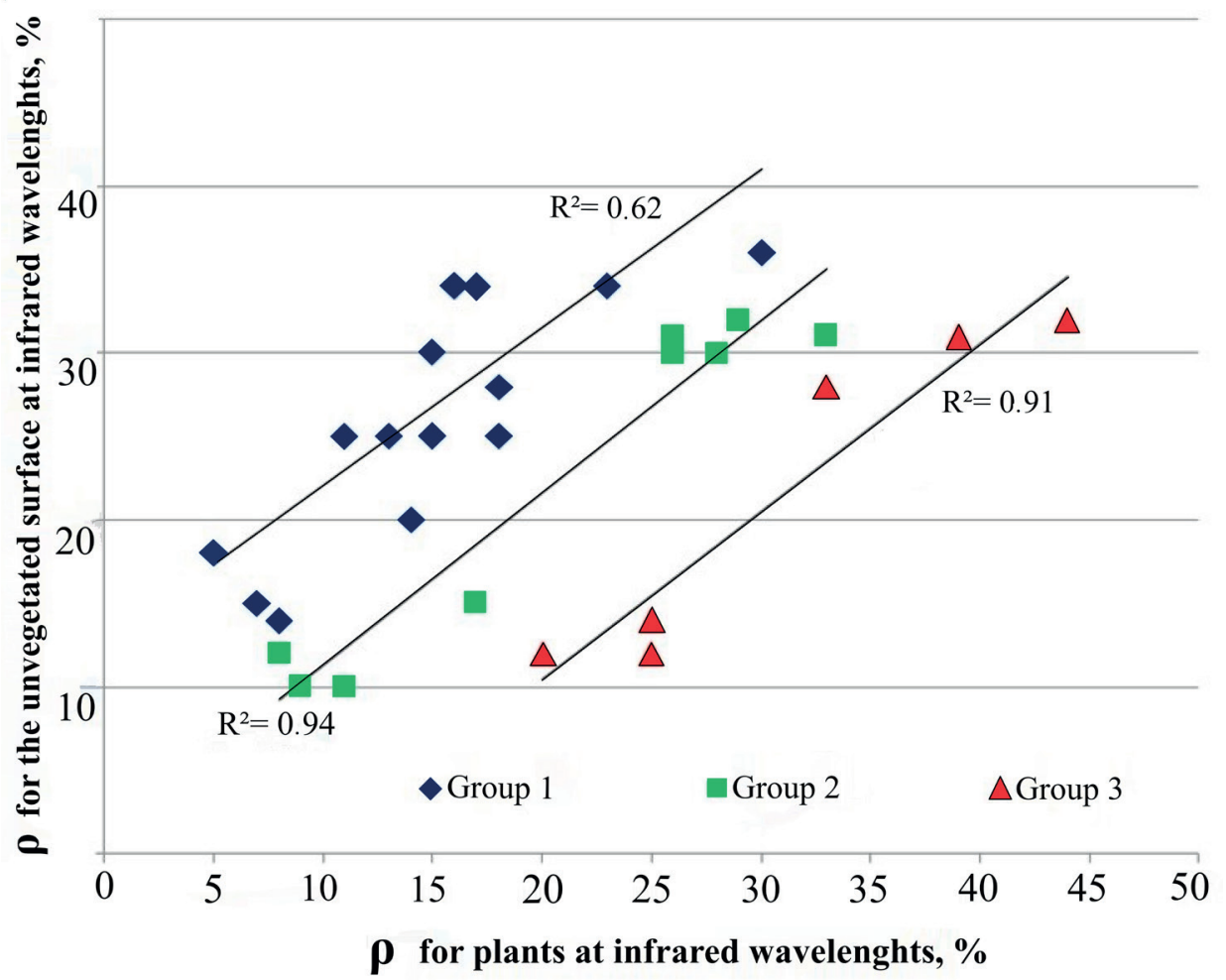

Fig. 3. The relationship between the total plants and unvegetated surface reflection coefficient at infrared wavelengths for 32 dominant plant species in different communities of Gobi. $k$-means clustering of the objects was performed

is characterised by roughly equal total plant and unvegetated surface coefficients (the difference is not more $5 \%$ ). Group 3 (Haloxylon ammodendron, Ephedra sinica, and Zygophyllum xanthoxylon) brings together plants, whose reflection intensity significantly exceeds that of the unvegetated surface. This group is the smallest.

It is impossible to identify plants characteristic of a certain group, since some of the species may belong to several groups, which is the case for Haloxylon ammodendron. This can be indicative of a complex interdependence between the reflectance of plants and the adjacent surface.

The most intensive absorption of solar radiation by plants was observed in the morning and at noon. However, when measuring the solar radiation reflected by Haloxylon ammodendron, Ephedra sinica and Zygophyllum xanthoxylon, the opposite phenomenon was detected - plants reflected more solar radiation at visible and infrared wavelengths than the unvegetated surface. These anomalous results may be explained by the structure of tree crowns, the phenological and physiological state of plants, as well as the weather conditions.
In the desert steppe of the Northern Gobi (C-1, C-2), measurements of reflected radiation were carried out on pasture under grazing and in enclosed areas. In the pasture area dominated by Stipa tianschanica+Convolvulus ammannii community, the projective cover did not exceed 10\% and the height of plants was less than $10 \mathrm{~cm}$, due to the livestock impact. In the non-pasture area dominated by a Stipa tianschanica+Allium polyrhizum community, the projective cover reached $15 \%$ and the plant height $15-20 \mathrm{~cm}$. Vegetation was of darker colour in the pasture and of lighter colour in the non-pasture area. Observations were performed in clear and windless weather in the morning on August 24, 2013.

It was found that the intensity of solar radiation reflected from the surface was minimum in the non-pasture (enclosed) area and maximum in the pasture (Fig. 4). The most significant differences were observed at visible wavelengths. In the nonpasture areas, the quantity of solar radiation at 525-625 nm wavelengths did not exceed $20 \%$, whereas, in the pasture areas, it was almost twice that level. At infrared wavelengths, SRR was more intense in the pasture than in the non-pasture area.

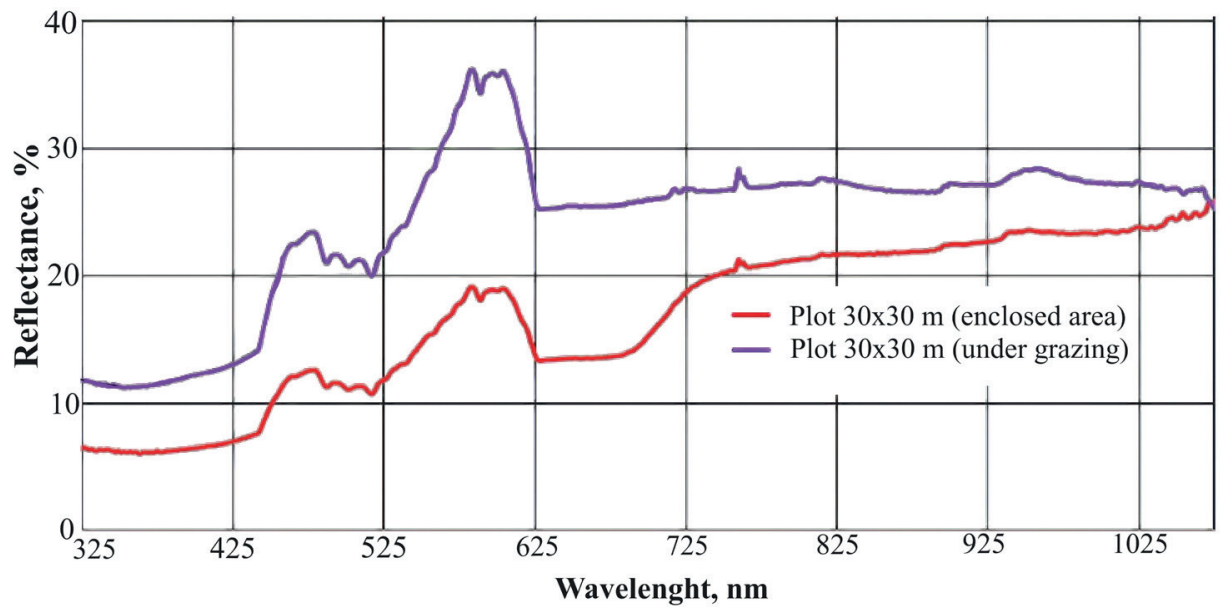

Fig. 4. Spectra of solar radiation reflectance in a desert steppe: in the non-pasture (enclosed) and pasture (under grazing) areas (24.08.2013; 10:00-10:22 a.m.) 
This data is consistent with the measurements of surface temperature in the pasture and enclosed areas. Observations were performed in clear and windless weather over 24 hours on August 24-25, 2013. The maximum soil surface temperature was $56.4^{\circ} \mathrm{C}$ in the nonpasture area and did not exceed $54^{\circ} \mathrm{C}$ in the pasture area. The frequency of occurrence of temperatures above $50^{\circ} \mathrm{C}$ was six in the pasture and almost 2.5 times that (15) in the non-pasture area. Average temperatures also differed. The average of 30 measurements reached $50.8^{\circ} \mathrm{C}$ in the nonpasture area and $48.1^{\circ} \mathrm{C}$ in the pasture. The difference between the soil surface temperature measured at night and in the morning in the pasture and non-pasture areas was negligible. The absolute minimum was observed at 7 a.m. local time $\left(12.5^{\circ} \mathrm{C}\right)$ in the pasture on August 25, 2013. The non-pasture absolute minimum was $13.5^{\circ} \mathrm{C}$ (Dedkov et al. 2017).

Thus, it was experimentally confirmed that the reflectance from a vegetated surface is lower than from an unvegetated surface. The total reflection coefficient of a large number of plants is lower than that of the unvegetated surface at visible and infrared wavelengths.

To prove this hypothesis, the average total plant and surface reflection coefficients (ATRC) were calculated for the considered wavelengths (a total of 32 plants). Table 2 shows the obtained values. The data are presented in the form $\bar{x} \pm \sigma_{\bar{x}}$, where $\bar{x}=\frac{1}{n} \sum_{i=1}^{n} x_{i}$ is the average value, $\sigma_{\bar{x}}=\sqrt{\frac{\sum_{1=1}^{n}\left(x_{i}-\bar{x}\right)^{2}}{n(n-1)}}$-root-mean-square error of the average value, and $n$ the number of elements in the sample.

The data shown in table 3 suggest that the projective cover has increased by $3-18 \%$ in the steppe and desert vegetation communities of Mongolian Gobi over the past 50 years. The average increase is $10 \%$, which is comparable to the data obtained by other researchers (Donohue et al. 2013).

\section{CONCLUSIONS}

The collected data was used to obtain a first approximation the contribution of the vegetation cover to the reduction in solar radiation from the day surface across the arid territories of Central Asia. According to Petrov (1973), the area of Central Asian deserts is $16.5 \mathrm{~m} \mathrm{~km}^{2}$. Approximately $10 \%$ of the desert area is covered with plants. The amount of solar radiation reflected from the surface of the Gobi

Table 2. Average values of the total reflection coefficient of plants and unvegetated surfaces

\begin{tabular}{|c|c|c|}
\hline Wavelengths & ATRC of plants, $\%$ & ATRC of surfaces, \% \\
\hline Visible & $19.7 \pm 1.4$ & $25.0 \pm 0.9$ \\
\hline Infrared & $20.1 \pm 1.7$ & $24.8 \pm 1.5$ \\
\hline
\end{tabular}

Table 3. Multidecadal changes in the projective cover in the desert and steppe zones of the Gobi, 1972-2013

\begin{tabular}{|c|c|c|c|c|c|c|}
\hline $\begin{array}{l}\text { Subzone/ } \\
\text { Index }\end{array}$ & $\begin{array}{c}\text { Year /Total PC } \\
(\%)\end{array}$ & $\begin{array}{c}\text { Year /Total PC } \\
(\%)\end{array}$ & Plant community & Plant species & $\begin{array}{c}\text { Year / Total PC } \\
(\%)\end{array}$ & $\begin{array}{c}\text { Year /Total PC } \\
(\%)\end{array}$ \\
\hline \multirow{3}{*}{$\begin{array}{l}\text { Middle } \\
\text { desert / } \\
\text { K-12 }\end{array}$} & \multirow{3}{*}{$\begin{array}{c}1972 / \\
10.2\end{array}$} & \multirow{3}{*}{$\begin{array}{c}2003 / \\
15.8\end{array}$} & \multirow{3}{*}{$\begin{array}{l}\text { [Zygophyllum xanthoxylon, } \\
\text { Nitraria sibirica] - } \\
\text { Brachanthemum gobicum + } \\
\text { Reaumuria soongarica }\end{array}$} & & 1972 & 2003 \\
\hline & & & & B. gobicum & 5.0 & 5.4 \\
\hline & & & & R. soongarica & 2.0 & 1.9 \\
\hline \multirow{5}{*}{$\begin{array}{l}\text { Desert } \\
\text { steppe / } \\
\text { C-2 }\end{array}$} & \multirow{5}{*}{$\begin{array}{c}1972 / \\
9.0\end{array}$} & \multirow{5}{*}{$\begin{array}{c}2003 / \\
11.8\end{array}$} & \multirow{5}{*}{$\begin{array}{l}\text { [Haloxylon ammodendron + } \\
\text { Zygophyllum xanthoxylon] } \\
\text { - Reaumuria soongarica + } \\
\text { Brachanthemum gobicum }\end{array}$} & & 1972 & 2003 \\
\hline & & & & R. soongarica & 3.0 & 3.4 \\
\hline & & & & B. gobicum & 0.8 & 0.8 \\
\hline & & & & Z.xanthoxylon & 1.3 & 0.5 \\
\hline & & & & H. ammodendron & 0.2 & 1.3 \\
\hline \multirow{4}{*}{$\begin{array}{l}\text { Mountain } \\
\text { steppe/ } \\
\text { GT-1 }\end{array}$} & \multirow{4}{*}{$\begin{array}{c}1993 / \\
15.5\end{array}$} & \multirow{4}{*}{$\begin{array}{c}2013 / \\
18.8\end{array}$} & \multirow{4}{*}{$\begin{array}{c}\text { Ephedra sinica + Ajania } \\
\text { fruticulosa + Allium polyrhizum }\end{array}$} & & 1993 & 2013 \\
\hline & & & & E. sinica & 7.0 & 12.0 \\
\hline & & & & A. fruticulosa & 1.8 & 2.2 \\
\hline & & & & A. polyrhizum & 1.5 & 2.5 \\
\hline \multirow{3}{*}{$\begin{array}{l}\text { Extra- arid } \\
\text { desert/ U-1, } \\
\text { U-2 }\end{array}$} & \multirow{3}{*}{$\begin{array}{l}1978 / \\
3.5\end{array}$} & \multirow{3}{*}{$\begin{array}{c}1993 / \\
22.6\end{array}$} & \multirow{3}{*}{$\begin{array}{l}\text { Haloxylon ammodendron + } \\
\text { Ephedra przewalskii }\end{array}$} & & 1978 & 1993 \\
\hline & & & & H. ammodendron & 3.0 & 22.0 \\
\hline & & & & E. przewalskii & 0.5 & 0.6 \\
\hline \multirow{4}{*}{$\begin{array}{c}\text { Middle } \\
\text { desert/ U-6 }\end{array}$} & \multirow{4}{*}{$\begin{array}{c}1978 / \\
3.2\end{array}$} & \multirow{4}{*}{$\begin{array}{l}1993 / \\
7.6\end{array}$} & \multirow{4}{*}{$\begin{array}{c}\text { Anabasis brevifolia + Stipa } \\
\text { caucasica + Allium polyrhizum }\end{array}$} & & 1978 & 2013 \\
\hline & & & & A. brevifolia & 2.5 & \multirow{3}{*}{ No data } \\
\hline & & & & A. polyrhizum & 0.3 & \\
\hline & & & & S. caucasica & 0.4 & \\
\hline
\end{tabular}


Desert in the summer months reaches $4 \mathrm{MJ} / \mathrm{m}^{2} /$ day (Gunin et al. 1980). Plants reduce solar radiation reflectance by $5 \%$. In the absence of vegetation and under normal conditions, the bare surface of the Central Asian deserts would reflect $66.1013 \mathrm{MJ} /$ day. A $10 \%$ projective cover accounts for a $5 \%$ change in reflectance and retains 3.3.1011 MJ/day or $0.5 \%$ of the total amount of energy reflected daily from the total day surface of the Central Asian deserts. In the Gobi Desert - given the same projective cover parameters - the amount of plant-retained energy will amount to 3.0-1010 MJ/day.

Thus, the overgrowth of deserts by plants increases not only the leaf surface area, projective cover, and biomass but also the amount of solar radiation retained at the surface, which affects the structure of the radiation and heat balance and the air temperature. According to the Choir, Sainshand, and Zamyn-Uud weather stations, the temperature increased by $1.2-2.3^{\circ} \mathrm{C}$ in the east of the Gobi desert over 25 years from 1989 to 2015. The projective cover, the leaf surface area, and biomass depend on precipitation, the amount of which differs from year to year. It can be assumed that the amount of solar radiation reflected by the vegetation cover on arid territories will differ under various weather conditions. Probably, deserts have a stronger effect on the reduction in solar radiation reflectance by the surface than other natural ecosystems do. Thus, they affect the structure of the radiation and heat balance as well as air temperature.

The accumulation of solar radiation by plants growing on arid territories was proven experimentally. The difference in reflection from the vegetated and unvegetated surfaces is $5 \%$, according to our estimates. Therefore, during daylight hours, the vegetated day surface releases less solar energy than the unvegetated surface does. This effect may be defined as a quasi- or secondary greenhouse effect - in the daytime, a portion of solar energy is not released from the surface but is rather retained by vegetation. This impulse, which seems to be insignificantly small at first glance, may trigger a series of climatic variations leading to a change in the structure of the radiation and heat balance as well as the climate of the desert-steppe and desert ecosystems in the Gobi.

\section{REFERENCES}

Archer S.R., Andersen E.M., Predick K.I., Schwinning S., Steidl R.J., Woods S.R. (2017). Woody Plant Encroachment: Causes and Consequences. In: Briske D. (eds) Rangeland Systems. Springer Series on Environmental Management. Springer, Cham, DOl: 10.1007/978-3-319-46709-2_2.

Bazha S.N., Gunin P.D., Danzhalova E.V., Drobyshev Yu.l., Kazantseva T.l., Ariunbold E., Myagmarsuren D., Khadbaatar S., Tserenkhand G. (2015). Invasive successions as an indicator of desertification of dry steppe by way of example of Central Mongolia. Russian Journal of Biological Invasion., [online] Available at: https://www.pleiades.online/cgi-perl/search.pl?type=abstract\&name=bioinv\&number=4\&year=1 5\&page=223. 6(4), 223-237, DOI: 10.1134/S2075111715040025.

Bonan G.B. Forests and climate change: forcings, feedbacks, and the climate benefits of forests. (2008). Science 320, 1444-1449.

Brovkin V. et al. (2013). Evaluation of vegetation cover and land-surface albedo in MPI-ESM CMIP5 simulations. J. Adv. Model. Earth Syst. 5, 48-57.

Buffington L. C. and C.H. Herbel (1965). Vegetational changes on a semidesert grassland range from 1858 to 1963. Ecological Monographs. 35 (2), 139-164.

Cherepanov A., Druzhinina E. (2009). Spectral characteristics of vegetation and vegetation indexes // Geomatics. [online] Available at: https://elibrary.ru/item.asp?id=22298135. 3, 28-32 (In Russian).

Collatz G.J., Bounoua L., Los S.O., Randall D.A., Fung I.Y. \& Sellers P.J. (2000). A mechanism for the influence of vegetation on the response of the diurnal temperature range to changing climate. Geophysical Research Letters, 27, 3381-3384.

Cyrus M. Kavwele, Johnstone K. Kimanzi, Mwangi J. Kinyanjui (2017). Impacts of Bush Encroachment on Wildlife Species Diversity, Composition, and Habitat Preference in Ol Pejeta Conservancy, Laikipia, Kenya. International Journal of Ecology, vol., Article ID 5620125, 6.

Dedkov V.P. (1989). The ecological niche and water balance of desert phytocenoses dominants. Leningrad State University Press: Leningrad, 264 (In Russian).

Dedkov V.P. (2016). On the influence of biotisation of Central Asian deserts on the changes in the surface temperature and the Earth's climate. In: Natural and anthropogenic changes in arid ecosystems and the struggle to combat desertification. Alef: Makhachkala. [online] Available at: https://elibrary.ru/item.asp?id=2751178346-49 (In Russian).

Dedkov V.P., Gunin P.D., Kazantseva T.I., Drobyshev Yu. I. (2017). The temperature of underlying surface in the arid zone of Mongolia ecosystems and the role of biota in its change. Russian Journal of Ecology. 48(1), 32-37, DOI: 10.1134/S1067413617010052.

D'Odorico P., Fuentes J.D., Pockman W.T., Collins S.L., He Y., Medeiros J.S., Litvak M.E. (2010). Positive feedback between microclimate and shrub encroachment in the northern Chihuahuan desert. Ecosphere, 1(6), art. 17, DOI: 10.1890/ES10-00073.1.

Donohue R.J., Roderick M.L., McVicar T.R., and Farquhar G.D. (2013). Impact of CO2 fertilisation on maximum foliage cover across the globe's warm, arid environments, Geophys. Res. Lett. 40(12), 3031-3035, DOl: 10.1002/grl.50563.

Fen Zhao, Bin Xu, Xiuchun Yang, Yunxiang Jin, Jinya Li, Lang Xia, Shi Chen and Hailong Ma. (2014). Remote Sensing Estimates of Grassland Aboveground Biomass Based on MODIS Net Primary Productivity (NPP): A Case Study in the Xilingol Grassland of Northern China. Remote Sens. [online] Available at: https://www.mdpi.com/2072-4292/6/6/5368. 6, 5368-5386.

Food and agriculture organization of the United Nation: [e-resource]. Available at: http://www.fao.org/home [Accessed 19 Sep. 2019].

Gradel A., Sukhbaatar G., Karthe D., Kang H. (2019). Forest Management In Mongolia - A Review Of Challenges And Lessons Learned With Special Reference To Degradation And Deforestation.GEOGRAPHY, ENVIRONMENT, SUSTAINABILITY, 12(3), 133-166, DOI: 10.24057/20719388-2019-102

Gunin P.D. \& Saandar M. Eds. (2019). Ecosystems of Mongolia Atlas. ADMON Print: Ulaanbaatar, 264.

Gunin P.D. (1990). The ecology of arid ecosystem desertification. VASKHNIL: Moscow, 354 (in Russian).

Gunin P.D., Bazha S.N., Danzhalova E.V., Dmitriev I.A., Drobyshev Yu.I., Kazantseva T.I., Miklyaeva I.M., Ogureeva G.N., Slemnev N.N. (2012). Expansion of Ephedra sinica Stapf. in the arid steppe ecosystems of eastern and central Mongolia. Arid Ecosystems. 2(1), 18-33, DOI: 10.1134/ S2079096112010052

Gunin P.D., Dedkov V.P. (1978). Ecological regimes of desert biogecenoses. Nauka: Moscow, 228 (in Russian). Gunin P.D., Vostokova E.A., Dorofeyuk N.I., Tarasov P.E., Black C. (1999). Vegetation Dynamics of Mongolia. Kluwer Acad. Publ., 238.

Heck P., Lüthi D., Wernli H., Schär Ch. (2001). Climate impacts of European scale anthropogenic vegetation changes: A sensitivity study using a regional climate model. Journal of Geophysical Research: Atmospheres. 106. Issue D8., 7817-7835. 
Iftikhar Ali, Fiona Cawkwell, Edward Dwyer, Brian Barrett and Stuart Green. (2016). Satellite remote sensing of grasslands: from observation to management. Journal of Plant Ecology. 9(6), 649-671, DOI: 10.1093/jpe/rtw005.

Kappas M.W., Propastin P.A. (2012). Review of Available Products of Leaf Area Index and Their Suitability over the Formerly Soviet Central Asia. Journal of Sensors. 2012, (ID 582159). 11, DOI: 10.1155/2012/582159.

Karnieli A., Bayarjargal Y., Bayasgalan M., Mandakh B., Dugarjav Ch., Burgheimer J., Khudulmur S., Bazha S.N. and Gunin P.D. (2013). Do vegetation indices provide a reliable indication of vegetation degradation? A case study in Mongolian pastures. International Journal of Remote Sensing. 34(17), 6243-6262.

Karthe D., Chalov S., Gradel A., Kusbach A. (2019). Special issue «Environment change on the Mongolian plateau: atmosphere, forests, soils and water». GEOGRAPHY, ENVIRONMENT, SUSTAINABILITY, 12(3), 60-65, DOI: 10.24057/2071-9388-2019-1411

Kazantseva T.I. (2009). Productivity of the zonal vegetation community of steppes and deserts in the Gobi part of Mongolia. Moscow: Nauka. 336 (in Russian with English summary).

Kazantseva T.I., Bazha S.N., Gunin P.D., Danzhalova E.V., Dedkov V.P., Drobyshev Yu.N., Dugarzhav Ch., Khadbaatar S. (2015). Long-term dynamics in the vegetation communities of desert steppes of Central Mongolia: The case of the Övörkhangai aimag. // Botanical Journal. 100(3), 249-270, DOl: 10.1134/ S0006813615030047 (in Russian with English summary).

Knapp A.K., Briggs J.M., Collins S.L., Archer S.R., Bret-Harte M.S., Ewers B.E., Peters D.P., Young D.R., Shaver G.R., Pendalland E., Cleary M.B. (2008). Shrub encroachment in North American grasslands: shifts in growth form dominance rapidly alters control of ecosystem carbon inputs. Global Change Biology. 14, 615-623, DOl: 10.1111/j.1365-2486.2007.01512.x.

MacQueen J. (1967). Some methods for classification and analysis of multivariate observations. Proc. 5th Berkeley Symp. on Math. Statistics and Probability. Univ. of Calif. Press. 281-297. [online] Available at: https://projecteuclid.org/euclid.bsmsp/1200512992. [Accessed 11 Jul. 2019].

Mark Chopping, Lihong Su, Albert Rango, John V. Martonchik, Debra P.C. Peters, Andrea Laliberte. (2008). Remote sensing of woody shrub cover in desert grasslands using MISR with a geometric-optical canopy reflectance model. Remote Sensing of Environment. 112(1), 19-34, DOI: 10.1016/j.rse.2006.04.023.

Petrov M.P. (1973). Deserts of the Earth. Nauka: Leningrad, 435 (In Russian).

Rusli N. \& Majid M.R. (2014). Monitoring and mapping leaf area index of rubber and oil palm in small watershed area. In: IOP Conference Series: Earth and Environmental Science. V. 18. [012036] Institute of Physics Publishing. [online] Available at: https://iopscience.iop.org/artic le/10.1088/1755-1315/18/1/012036, DOl: 10.1088/1755-1315/18/1/012036.

Shulgin I.A. (1973). Plants and the Sun. Gidrometeoizdat: Leningrad, 251 (in Russian).

Sibanda M., Mutanga O., Mathieu Rouget M. and Kumar L. (2017). Estimating Biomass of Native Grass Grown under Complex Management Treatments Using WorldView-3 Spectral Derivatives. Remote Sens. 9(1), 55, 1-21. [online] Available at: https://www.mdpi. com/2072-4292/9/1/55, DOI: 10.3390/rs9010055.

Slemnev N.N., Gunin P.D., Kazantseva T.I. (1994). On the natural seed regeneration of dominant plants in the ecosystems of Mongolia's deserts. Plant resources. 30(4), 1-5 (in Russian with English summary).

The Plant List // http://www.theplantlist.org/ [Accessed 1 May. 2020].

Van Auken O.W. (2000). Shrub invasions of North American semiarid grasslands. nnual Review of Ecological Systems. 31, $197-215$. [online] Available at: https://www.jstor.org/stable/221730?seq=1.

Zalibekov Z.G., Novikova N.M. (2016). Research and applied framework for a planetary strategy for combating desertification./in: Natural and anthropogenic changes in arid ecosystems and the struggle to combat desertification. Alef: Makhachkala, 31-37. [online] Available at: https://elibrary.ru/item.asp?id=27511780. 